\title{
Regulation of Cell-Based Therapies in Europe: Current Challenges and Emerging Issues
}

Alessandro Blasimme* and Emmanuelle Rial-Sebbag

\section{ABSTRACT}

Europe is ready to deploy its immense capital of knowledge into the development of effective cell-based therapies and delve into the global race for translating stem cell science into regenerative medicine. But what are the challenges and the emerging issues that lay ahead the realization of Europe's enormous potential in this field? Both researchers and industrial stakeholders tend to impute the slow pace of translation to specific suboptimal features of the regulatory environment in Europe. At the same time, a host of new issues are emerging as testified by a recent public controversy regarding the provision of unproven cell therapy in Italy. We will review this topic and suggest some solutions to foster the responsible development of innovative cell-based therapies in Europe.

\section{INTRODUCTION}

Europe is ready to deploy its immense capital of knowledge for the development of effective cell-based therapies and to delve into the global race for translating stem cell science into regenerative medicine. But what are the challenges and the emerging issues that lie ahead of the realization of Europe's enormous potential in this field?

This is a time of economic crisis, in Europe as well as in other parts of the world. How-

INSERM UMR 1027 Département d'épidémiologie et de santé publique, Faculté de Médecine, Université Paul Sabatier-Toulouse III, Toulouse, France.

*(Correspondence: alessandro.

blasimme@inserm.fr) ever, while the present economic crisis per se may be conducive to reduced spending on science in Europe, some Member States are starting to realize that biomedical innovation can be an opportunity for economic recovery [101] and thus decide to prioritize at least some domains of biomedicine- such as regenerative medicinethat hold great promise to deliver new cures and, according to some, reduce soaring healthcare expenditures throughout the continent in the long run [102].

To unleash the therapeutic potential of European stem cell science, sustained public and private investment in this sector is certainly required, but also, and equally importantly, a solid and efficient regulatory framework must be put to work. In this respect, the European Union and Member States share their legal competencies both in public health and on the realization of the internal market, in particular with respect to the free movements of goods (including medicinal products).

It has been estimated that between 2004 and 2010, 318 regenerative medicine clinical trials were initiated in Europe, 78\% $(n=248)$ of which are relative to cellbased medicinal products [1]. To date, however, only two regenerative medicine products obtained marketing authorization as advanced therapy medicinal products 
(ATMPs) by the European Medicines Agency (EMA): Glybera, a gene therapy product by UniQure to treat lipoprotein lipase deficiency (a severe form of pancreatitis), and Chondrocelect, an autologous cell therapy for cartilage regeneration by Tigenix.

Other scientifically advanced countries such as the United States, Canada, and Japan have not approved more new cellular therapies than Europe. However, both researchers and industrial stakeholders tend to impute the slow pace of translation to specific suboptimal features of the regulatory environment in Europe. Expectations are thus growing for the pipeline to be improved. At the same time, a host of new issues are emerging as testified by a recent public controversy regarding the provision of unproven cell therapy in Italy.

\section{Current challenges in the governance of innovative cell therapies}

The translational pipeline from basic research to the delivery of innovative stem cell-based therapies is covered by a variety of European legal instruments [2] ranging from regulations on marketing authorization (Regulation (EC) no. 1394/2007) to Directives about clinical trials (Directive 2001/20/EC) and guidelines of good clinical practice (Directive 2001/83/EC, Directive 2009/120/EC) (Fig. 1). In addition, each Member State has to implement these provisions at the national level, thus accounting for a second level of heterogeneity. In this respect, the legal regulation is far from being totally homogeneous in Europe $[3,4]$, and therefore not all the steps in the translational pipeline are equally addressed from a legal point of view [5]. This leads to heterogeneity in the legal requirements to be fulfilled in the various Members States, a factor that can be seen as slowing down the innovation process.

In December 2012, almost 6 years after the approval of the Regulation setting up

\section{FIG. 1. Scheme depicting European legal texts of relevance to cell-based medicine: tissue and cell Directives, clinical trial Directives, and advanced therapy medicinal products, Regulation.}

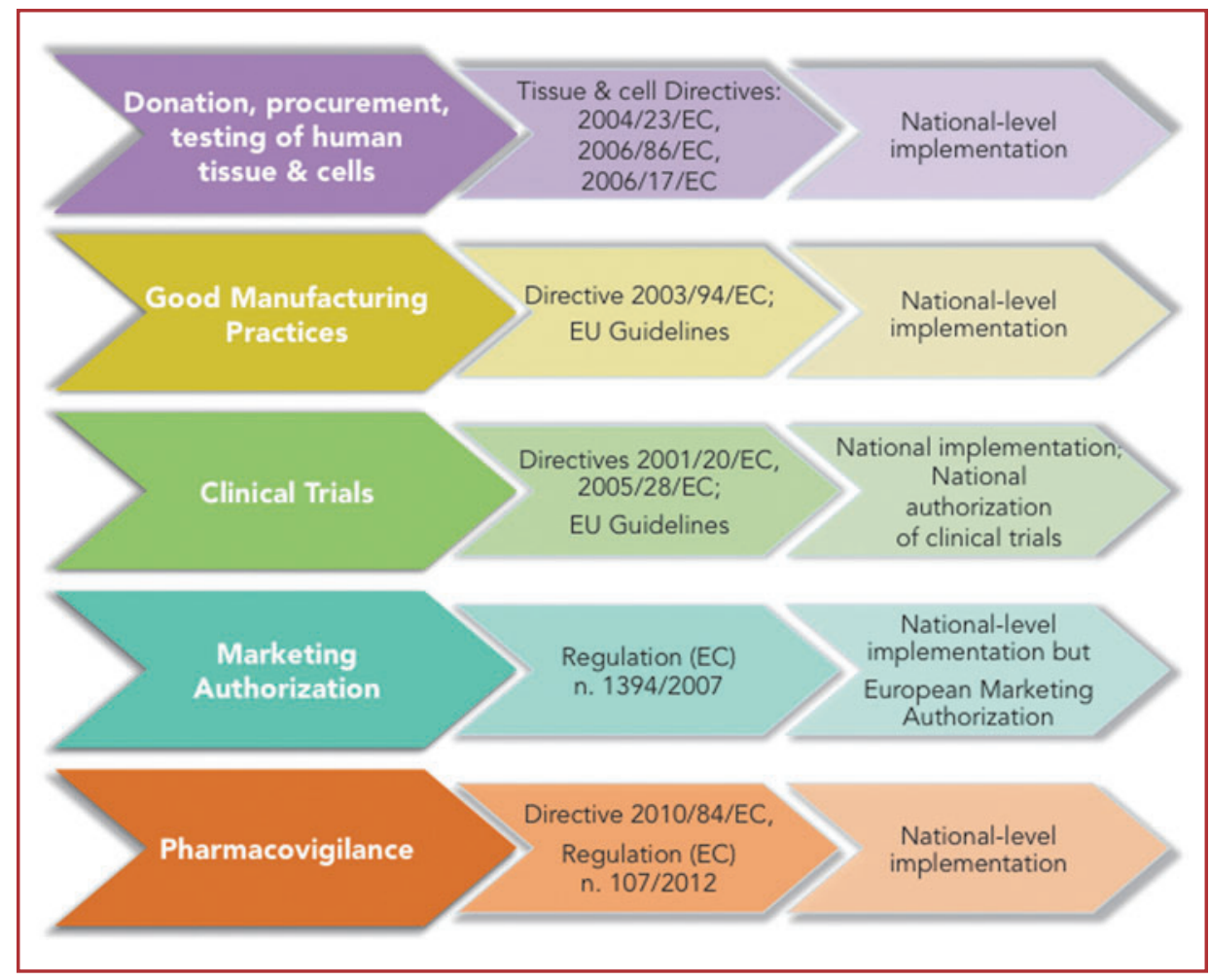

a centralized procedure for marketing authorization of ATMPs (Fig. 1), the Directorate General for Health and Consumers of the European Commission launched a public consultation on how the requirements laid down by the Regulation fare with respect to the needs and expectations of researchers, clinicians, patients, national regulatory agencies, and the industry. ${ }^{1}$

It turned out that the European regulatory pathway is perceived as very demanding, especially for academic institutions and small and medium enterprises that, while constituting the bulk of those attempting the clinical translation of stem cell biology, are less experienced than big pharmaceutical companies in navigating a complex regulatory environment. This is

${ }^{1} \mathrm{~A}$ summary of the public consultation can be found here: http://ec.europa.eu/health/humanuse/advanced-therapies/developments/2013_ pc_atmp.htm said to account, at least in part, for the current stagnation in new marketing authorizations for ATMPs.

Another aspect of the current regulation that is often highlighted is the lack of clarity in certain important requirementsnamely, the notion of substantial manipulation, that of nonhomologous use and, finally, that of hospital exemption. While the former categories create ambiguity in the classification of ATMPs, the latter is seen as a disincentive to engage in the complex, lengthy, and expensive pathway that should lead to marketing approval.

A clearer and better-defined regulatory pathway, many argue, would be more encouraging for investors. To this aim, better coordination between the EMA and national regulatory agencies would be appropriate, so that researchers and their commercial partners can receive improved advice on the complex requirements for ATMP approval. 
Some stakeholders in the field also point out that the ATMP Regulation should be more specific, especially as to technical requirements for clinical trials and good manufacturing practices for advanced therapies: cells are inherently more variable than conventional chemical compounds and, since they are viable, it is obviously hard to fully assimilate them to drugs. This calls for more specific safety and efficacy criteria. Moreover, quite a number of promising advanced therapies in an early translational phase target rare diseases [6,7] and may be difficult to validate on large cohorts: this has to be taken into account, and clinical trial design has to be adapted accordingly.

Overall, it is important that the pathway from phase 1 to marketing approval be streamlined, that researchers and companies receive enough support from national and European regulatory agencies in navigating the system, and that the intricate legal landscape constituted by the ATMP Regulation, the clinical trial Directive, and the tissue and cells Directives (Fig. 1) is harmonized and simplified. In this last respect, while many concur that the centralized marketing authorization procedure established by ATMP requires clarification, not enough attention has been given so far to the issue of harmonization of the whole regulatory pipeline from research-thereby including the procurement, storage, and distribution of human material - to clinical use.

To this aim we promoted EUCelLEX ${ }^{2}$ (coordinated by Emmanuelle Rial-Sebbag), an FP7 coordination action that brings together a number of European and international experts and stakeholders in the ethical, legal, and social issues that surround cell-based regenerative medicine: the aim of the consortium is to assess the adequacy of the present European regulatory framework for the use of stem cells and to provide recommendations that may facilitate it in all aspects from research to healthcare applications.

${ }^{2}$ EUCelLEX is funded by the European Commission under the Seventh Framework Programme.
A further challenge for the development of cell-based therapies in Europe has to do with the fact that, notwithstanding the existence of a centralized marketing authorization procedure for ATMPs, other crucial aspects of the translational pipeline are still delegated to the individual Member States. For example, whereby the regulatory requirements are set at the European level, the creation of the clinical infrastructure remains largely of national competence. Therefore, since development of innovative cell therapies still requires conspicuous public investments at the national level, chances are that this will create competition instead of collaboration among Member States.

Moreover, national healthcare systems will have to adapt to the specificities of innovative products such as new cell therapies, both in terms of evaluation procedures and in terms of reimbursement policies. This aspect of regenerative medicine in Europe has been evaded for too long. In a not-too-distant future, we may have to cope with a catalog of cell-based products approved for being marketed throughout Europe, but we may lack a harmonized scheme for making them available to all European patients. This may eventually push regenerative medicine into the private market and potentially create inequalities of access to new products among European citizens.

\section{Emerging issues: hope, hype, and innovation}

Expectations are high on the part of patients and their families, who see in innovative cell therapies their unique - and sometimes last - hope. However, it takes time for regenerative medicine products to reach the European market (so that in some cases, applications for marketing authorization have been withdrawn by the sponsors, as in the case of Advexin and Cerepro) and to meet those expectations. Probably also as a consequence of this lengthiness, parallel "unorthodox" offers of untested therapies are flourish- ing in European countries and worldwide, not rarely with deleterious consequences for patients undergoing unproven therapies (Fig. 2). In this context, attention must be paid to the fact that different routes to implementing European Directives and Regulations may be taken by different Member States. This is especially true for the so-called hospital exemption clause [8] and can result in loopholes to be exploited by providers of unproven therapies, thus encouraging intra-European stem cell tourism and the activity of clinics offering yet untested stem cell treatments.

A recent case demonstrates that, notwithstanding the existence of a regulatory framework that, as we said, is perceived by some as rigid and restrictive, things can, nonetheless, go wild for regenerative medicine in Europe.

A recent judiciary investigation uncovered that, since 2009, a private group based in northern Italy called Stamina Foundation has been offering mostly allogenic intravenous injections of bone marrow aspirations allegedly containing mesenchymal stem cells to patients affected by a variety of debilitating conditions ranging from Parkinson's disease to metachromatic leukodystrophy, Niemann-Pick disease, and spinal muscular atrophy.

Apparently, Stamina used to charge patients at least until recently, when the organization stipulated official agreements with two public hospitals in the north of Italy, claiming to be acting under the compassionate use framework. The case occasioned an investigation followed by and inspection by the Italian medicines agency (Agenzia Italiana del Farmaco, AIFA). The inspection revealed that Stamina did not comply with a number of regulatory requirements for the compassionate use of cell therapy in Italy; most importantly, AIFA found out that no published preclinical and clinical evidence supports the Stamina procedure.

On May 15, 2012, AIFA issued a formal inhibitory order to stop Stamina's activi- 
FIG. 2. Casualties and controversies with unproven stem cell based therapies in Europe.

\begin{tabular}{|c|c|c|}
\hline Italy & Germany & Hungary \\
\hline $\begin{array}{l}\text { - } 72 \text {-year-old man affected } \\
\text { by Parkinson's disease died } \\
\text { in } 2009 \text { after autologous } \\
\text { stem cell injection by } \\
\text { an Italian doctor (now } \\
\text { Stamina's scientific director } \\
\text { - see main text) in a clinic } \\
\text { located in the Republic of } \\
\text { San Marino. } \\
\text { - Family members suspect } \\
\text { the death is directly linked } \\
\text { to the procedure, but } \\
\text { doctor claims the patient } \\
\text { died for other causes. The } \\
\text { case has not yet been } \\
\text { decided by Italian courts, } \\
\text { but gave rise to an } \\
\text { investigation [105]. }\end{array}$ & $\begin{array}{l}\text { - XCell, a German clinical } \\
\text { center charging patients for } \\
\text { injections of autologous } \\
\text { bone marrow-derived cell, } \\
\text { closed in } 2011 \text { after the } \\
\text { death of a } 18 \text {-month-old } \\
\text { Romanian child following } \\
\text { cell-injections in the brain. } \\
{[12,106] \text {. }} \\
\text { - xCell has now moved from } \\
\text { Germany and operates in } \\
\text { Lebanon and India as } \\
\text { Cell4health [107]. }\end{array}$ & $\begin{array}{l}\text { - In July } 2009 \text { Hungarian } \\
\text { police detained four } \\
\text { individuals suspected of } \\
\text { providing illegal stem cell } \\
\text { treatments using cells from } \\
\text { embryos or aborted fetuses } \\
\text { [108]. } \\
\text { - The alleged treatments } \\
\text { were administered in a } \\
\text { private clinic in Budapest for } \\
\text { a cost of about } 20,000 € \text {. For } \\
\text { cell preparation, the clinic } \\
\text { relied on a private stem cell } \\
\text { research institute. }\end{array}$ \\
\hline
\end{tabular}

ties. This decision caused a number of patients-most of them very young children - to stop receiving injections. In reaction to this outcome, many families turned to courts and, thanks to surprising judicial decisions based on testimony by children's parents, obtained counterinjunctions to continue with the injections. So far, more than 100 patients were accorded judicial permission to receive Stamina's infusions.

Especially in this early phase, public opinion, after one-sided media reports showing desperate families and their sick children, seemed to be unequivocally supportive of the Stamina method, despite numerous warnings from the scientific community. As a consequence, the regulatory requirements set up to protect patients' safety started to be perceived as unjust obstacles to families and patients claiming access to the injections as their last therapeutic hope. The mounting pressure resulted in late March 2013 in an ad hoc decree by the Ministry of Health that gave Stamina permission to derogate from existing norms and continue the treatment for the patients who had already started it, at the expense of taxpayers' money.
As the decree underwent the usual parliamentary ratification process, a further decision was taken by the House of Representatives: the sum of $€ 3$ million was allocated to sponsor a public clinical trial to test for the safety and efficacy of the Stamina method. The starting date of the trial has, however, been postponed because of Stamina's reluctance to provide their protocol to the Italian regulatory agencies. Finally, the protocol was provided, but the Ministry of Health decided to keep it secret and not to share it with the public and the scientific community. The case, in the meantime, trespassed the Italian borders as prominent scientists of international renown forcefully criticized both Stamina and the political decisions taken in this case [9-11,103]. So did the EMA [104].

The Stamina case is a vivid reminder that the governance of scientific and technological novelties is challenging, especially when the hopes of desperate patients encounter the rush to offer unproven therapies skipping clinical validation. In this climate, claims about therapeutic freedom and patients' right to early access of cell-based therapies can easily gain consensus. They are, however, ethically unjustified and, if translated into a deregulated governance of regenerative medicine, they can indeed hinder its development toward safe and effective cures. Those derogations to the scope of the current legal framework, both at European and national level, call for a deeper appraisal of current practices in Europe and for proposing recommendations for improved coordination and regulation (see EUCelLEX project).

The development of innovative cell therapies should be perceived as a shared responsibility. Although regulatory power is ultimately in the hands of appointed officials, steering clinical translation toward new therapies in an ethically acceptable way depends on a participated effort by all relevant stakeholders: bioethicists, lawyers and social sciences scholars, regulators, scientists, scientific societies, companies, patients' advocates, and the media. Each of these actors can make a difference in how progress in regenerative medicine is communicated to lay publics as well as in the way regulatory jurisdiction by competent authorities is perceived and implemented.

In particular, the Stamina controversy invites more careful ethical and legal analysis of the stakes at play for vulnerable categories of patients such as the very young, those affected by incurable or rare diseases, and the elderly. Their interests do not seem to be enhanced by deregulation of the kind we see in Italy: quite to the contrary, as major advocacy groups have rightly claimed, they need a regulatory environment that guarantees respect for them as persons, patients, and potential research participants (Fig. 3).

\section{CONCLUSION}

To exploit the full therapeutic potential of European stem cell science, the regulatory pathway to centralized marketing authorization for ATMPs in Europe will have to be clarified, streamlined, and simplified. But adjusting the existing framework to avoid unnecessary regulatory 
FIG. 3. Recapitulation of challenges and emerging issues.

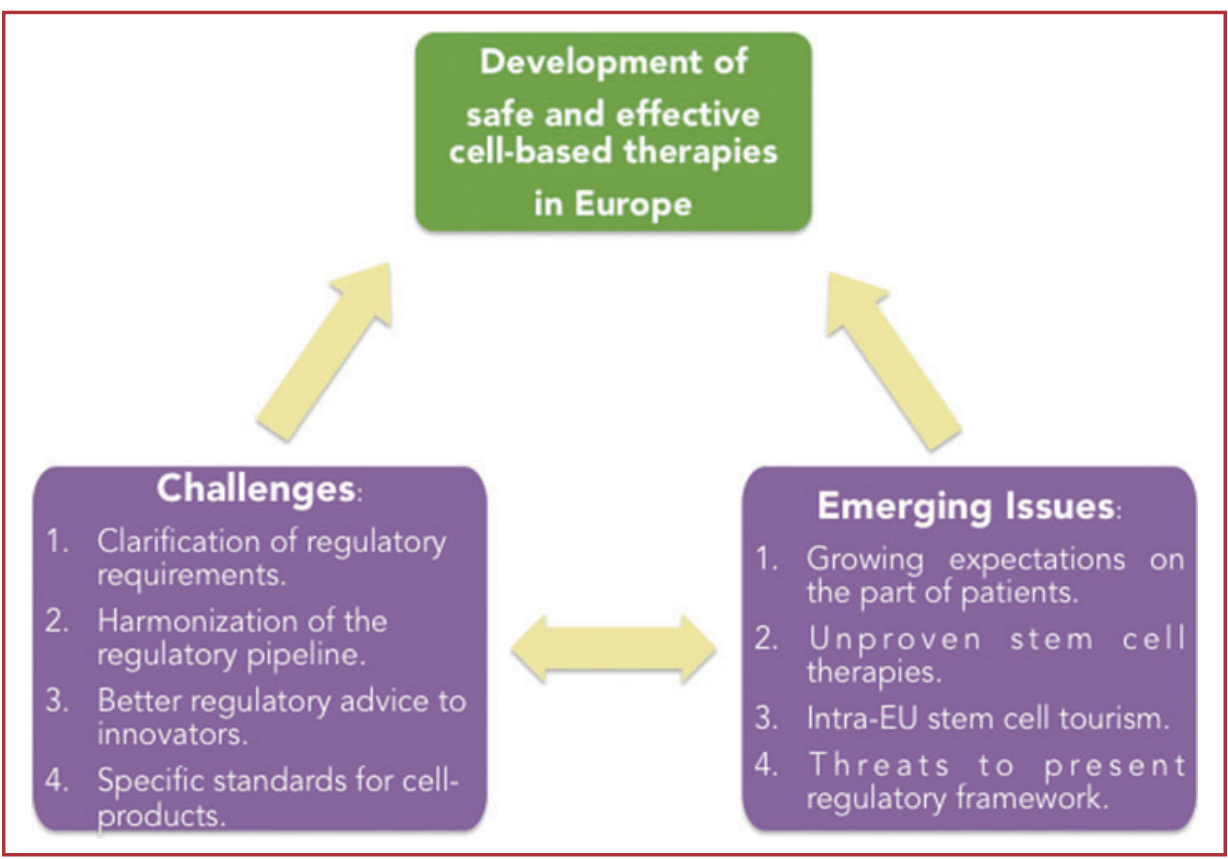

burden does not mean deregulation. Emerging issues relative to unproven cell therapies strikingly recall that we must remain vigilant about possible misuses.

The Italian case suggests that in Europe there is room for science policy decisions that contradict the established regulatory framework. The latter, while imperfect and amenable to improvement, at the very least offers a necessary reference for the field. Precipitous revisions of current regulatory norms can represent a concrete impediment to the advancement of regenerative medicine especially when, like we saw, they encourage legislative activities to follow suite emotional waves of public opinion.

In this respect, it is important to close the regulatory loopholes caused by different implementation strategies in different member states. This is crucial to avoid because what is illegal in one European country can be pursued in a neighboring one, thus undermining the efficacy of the European regulatory edifice. Furthermore, Europe should reflect on a good strategy to discourage stem cell tourism to third countries where unproven thera- pies can be offered to European patients under less strict and less controlled regulatory conditions. Regulatory challenges for the development of regenerative medicine in Europe have to be tackled in a proportionate and responsible way, that is, with the necessary awareness about both regulatory efficacy and possible misuses of innovation.

More work needs to be done to develop solid scientific [11] and ethical standards specifically adapted to the clinical translation of regenerative medicine. This entails acknowledging the uncertainties that lay ahead the realization of the therapeutic potential of stem cells in Europe-be them technical, ethical, legal, or societal. Especially in a time of economic crisis for Europe, promising fields of biomedical innovation represent the occasion for an upturn. Different stakeholders, however, are likely to have different ideas about the future of regenerative medicine - ideas that can be promoted or frustrated depending on the regulatory choices that will be taken in the coming years. Occasions should thus be abundant not only for discussing, but also for renegotiating the values, visions, and interests that different regulatory options embed [109]. It is exactly at this point that Europe needs a good deal of reflexive thinking in shaping the future of cell-based therapies [13].

\section{ACKNOWLEDGMENTS}

We would like to thank Aurélie Mahalatchimy (INSERM UMR 1027 and Université Toulouse Capitole) for help with the preparation of Figure 1 and for insightful discussions while drafting this paper. The EUcelLEX project, funded under the FP7, grant agreement no 601806.

\section{Author disclosure statement}

No competing financial interests exist.

\section{REFERENCES}

\section{Primary Literature}

1. Maciulaitis R, L D’Apote, A Buchanan, L Pioppo and CK Schneider. (2013). Clinical development of advanced therapy medicinal products in Europe: evidence that regulators must be proactive. Mol Ther 20:479-482.

2. Migliaccio G and C Pintus. (2012). Role of the EU framework in regulation of stem cell-based products. Adv Biochem Eng Biotechnol. [Epub ahead of print] 3. Ancans J. (2012). Cell therapy medicinal product regulatory framework in Europe and its application for MSC-based therapy development. Front Immunol 3:253.

4. Mahalatchimy A, E Rial-Sebbag, V Tournay and A Faulkner. (2012). The legal landscape for advanced therapies: material and institutional implementation of European Union rules in France and the United Kingdom. J Law Soc 39:131-149. 5. Favale M and A Plomer. (2009). Fundamental disjunctions in the EU legal order on human tissue, cells \& advanced regenerative therapies. Maastricht J Eur Comp 16:89.

6. Aiuti A, L Biasco, S Scaramuzza, F Ferrua, MP Cicalese, C Baricordi, et al. (2013). Lentiviral hematopoietic stem 
cell gene therapy in patients with WiskottAldrich syndrome. Science 341:1233151.

7. Biffi A, E Montini, L Lorioli, M Cesani, F Fumagalli, T Plati, et al. (2013). Lentiviral hematopoietic stem cell gene therapy benefits metachromatic leukodystrophy. Science 341:1233158.

8. Rahbari M and NN Rahbari. (2011). Compassionate use of medicinal products in Europe: current status and perspectives. Bull World Health Organ 89:163.

9. Abbott A. (2012). Stem-cell ruling riles researchers. Nature 495:418-419.

10. Bianco P. (2013). Don’t market stem-cell products ahead of proof. Nature 499:255.

11. Bianco P, R Barker, O Brüstle, E Cattaneo, H Clevers, GQ Daley, et al. (2013). Regulation of stem cell therapies under attack in Europe: for whom the bell tolls. EMBO J 32:1489-1495.

12. Stafford N. (2009). Germany tightens law on stem cell treatments. BMJ 339:b2967. 13. Meslin EM, A Blasimme and A Cambon-Thomsen. (2013). Mapping the trans- lational science policy «Valley of Death». Clin Transl Med 2:14.

\section{Websites}

101. House of Lords, Science \& Technology Committee. (2013). Regenerative Medicine Report. www.publications.par liament.uk/pa/ld201314/ldselect/ldsctech/ 23/23.pdf

102. Department for Business Innovation \& Skills. (2011). Taking Stock of Regenerative Medicine in the United Kingdom. www.bis.gov.uk/assets/biscore/innovation /docs/t/11-1056-taking-stock-of-regener ative-medicine

103. Abbott A. Italian stem-cell trial based on flawed data. Nature, July 2, 2013. www.nature.com/news/italian-stemcell-trial-based-on-flawed-data-1.13329 104. EMA. (2013). Stem cell therapy treatments. www.ema.europa.eu/ema/index.jsp ?curl=pages/news_and_events/news / 2013/04/news_detail_001769.jsp\&mid $=\mathrm{WC} 0 \mathrm{~b} 01 \mathrm{ac} 058004 \mathrm{~d} 5 \mathrm{cl}$
105. Innesti di staminali al Burlo, indagano i pm di Torino-Cronaca-Il Piccolo. http://ilpiccolo.gelocal.it/cronaca/ 2009/12/30/news/innesti-di-staminali-alburlo-indagano-i-pm-di-torino-1.12591

106. Abbott A. (2011). Nature Newsblog. http://blogs.nature.com/news/2011/05/noto rious_stem_cell therapy_ce_1.html

107. Mendick $\bar{R}$. Stem cell clinic that «preyed on the vulnerable». Telegraph. co.uk. www.telegraph.co.uk/health/healt hnews/9192157/Stem-cell-clinic-thatpreyed-on-the-vulnerable.html

108. Than K. (2009). Hungary detains 4 over illegal stem cell treatment. Reuters. www.reuters.com/article/2009/07/29/ us-hungary-stemcell-idUSTRE56S4PR 20090729

109. European Science Foundation. (2013). Science in society: caring for our futures in turbulent times. www.esf.org/media -centre/ext-single-news/article/science-in -society-caring-for-our-futures-in-turbu lent-times-967.html 